\title{
Öğretmenler İçin Göreceli Yoksunluk Ölçeği Geliştirme Çalışması
}

\author{
Olcay Altınlı a, b, N. Bilge Uzun ${ }^{c}$,Yusuf İnand ${ }^{\mathrm{d}}$
}

$\mathrm{Bu}$ araştırma öğretmenlerin göreceli yoksunluk algılarını belirlemeye yönelik Göreceli Yoksunluk Ölçeğini geliştirmek amacıyla yapılmıştır. Araştırmanın çalışma grubu Millı̂ Eğitim Bakanlığı'na bağlı devlet ve özel okullarda çalışan 427 öğretmen oluşturmaktadır. Göreceli Yoksunluk Ölçeği için 46 maddeden oluşan bir madde havuzu oluşturulmuştur. Ölçek için toplanan verilerin faktör analizi için uygunluğunu belirlemek amacıyla yapılan KMO test değeri; 0,899 olarak hesaplanmıştır. Ölçeğin kapsam geçerliliğini sağlamak amacıyla uzman görüşü alınmıştır. Ayrıca Göreceli Yoksunluk Ölçeğinin açıkladığı toplam varyans oranı ise \% 48,590'dır. Açımlayıcı faktör analizi sonucu ölçeğin üç faktörden oluştuğu görülmüştür. Bu faktörler sırasıyla "Yönetimsel Yoksunluk", "Kişisel Yoksunluk ", "Gelişimsel Yoksunluk" şeklindedir. Göreceli Yoksunluk için hesaplanan iç tutarlılık katsayısı 0,78' dir. Bunun yanında ölçeğin yapı geçerliliğini test etmek için doğrulayıcı faktör analizi yapılmıştır. Elde edilen değerler ölçeğin geçerli ve güvenilir olduğunu göstermiştir.

\begin{tabular}{r} 
Anahtar Kelimeler \\
\hline Göreceli Yoksunluk \\
Öğretmen \\
Göreceli Yoksunluk Ölçeği \\
Yoksunluk \\
Makale Hakkında \\
\hline Geliş Tarihi: 21.07 .2021 \\
Kabul Tarihi: 24.09 .2021
\end{tabular}

Doi: 10.18026/cbayarsos.973645

\section{Developing a Relative Deprivation Scale for Teachers}

\begin{abstract}
This research aimed to develop the Relative Deprivation Scale to determine teachers' perceptions of relative deprivation. The study group of the research consisted of 427 teachers working in public and private schools affiliated with the Ministry of National Education. A total of 46 items were created for the scale. The KMO test value, which was conducted to determine the suitability of the data for factor analysis, was calculated as 0.899. Expert opinion was taken to ensure the content validity of the scale. The Relative Deprivation Scale explained $48,590 \%$ of the total variance. As a result of exploratory factor analysis, it was seen that the scale consisted of three factors: "Administrative Deprivation", "Personal Deprivation" and "Developmental Deprivation". The internal consistency coefficient calculated for the Relative Deprivation Scale is 0.78. In addition, confirmatory factor analysis was performed to test the construct validity of the scale. The obtained values showed that the scale was valid and reliable.
\end{abstract}

Keywords

Relative Deprivation

Teacher

Relative Deprivation Scale

Deprivation

\section{About Article}

Received: 21.07 .2021

Accepted: 24.09.2021

Doi: $10.18026 /$ cbayarsos. 973645

\footnotetext{
a İletişim Yazarı: inandi@mersin.edu.tr

b Yüksek Lisans Öğrencisi, Mersin Üniversitesi, Eğitim Fakültesi. olcay-eren@hotmail.com ORCID: 0000-0002-9197-5828

c Doç. Dr., Mersin Üniversitesi, Eğitim Fakültesi. n.bilgeuzun@gmail.com ORCID: 0000-0003-2293-4536

d Doç. Dr., Mersin Üniversitesi, Eğitim Fakültesi. inandiyusuf@gmail.com ORCID: 0000-0003-2760-0957
} 


\section{Giriş}

İlk örgütlerin kurulmasından bu yana geçen sürede insana verilen değer her geçen gün artmaktadır. Başlangıçta sadece makinaya ve çıktıya önem veren örgütler zaman içinde verimliliğin ve kalitenin düşmesi sonucu çeşitli arayışlar içine girmişlerdir. Bunun sonucunda da çalışanların sadece makinanın bir parçası gibi görülmeyeceği onların psiko- sosyal ihtiyaçlarının da olabileceği ve bunların karşılanması sonucunda ürünlerin daha kaliteli ve örgütlerin hedeflerine daha kısa sürede ulaşabileceğini ortaya koymuşlardır. Benzer süreçler eğitim örgütlerinde de yaşanmış, bu geleneksel anlayıştan insan merkezli anlayışa geçişle birlikte eğitim örgütlerinde çalışanlarında okul içi ve dışındaki tüm değişkenlerin bireyleri etkileyebileceği dikkate alınmaya başlanmıştır. Eğitim örgütleri içinde ise temel olarak öğretmenler ön plana çıkmaktadır. Eğitim örgütlerinde aslolan öğretmenliktir sözü öğretmenlerin eğitim örgütleri için ne kadar önemli olduğunun da bir göstergesidir. Eğitim örgütleri için hayati bir öneme sahip öğretmenlerin ise; iş doyumlarının, örgütsel bağlılıklarının ve örgütsel adanmışlıklarının yüksek, yabancılaşmalarının, tükenmişliklerinin ve sessizliklerinin düşük olması sağlanmalıdır. Yine örgütsel güven ve örgütsel adaletin tam olması ve öğretmenlerin kendilerine karşı bir haksızlığın yapılmadığına inanması gerekir ki, olumlu bir örgüt kültürü oluşsun ve bu olumlu kültürün etkisiyle istendik hedeflere ulaşılsın. Olumlu bir kültürün oluşması için gereken değişkenlerden birinin de öğretmenlerin kendilerine karşı bir haksızlığın yapılmadı̆̆ına olan inanışlarıdır. Öğretmenler eğitim hedeflerine ulaşmak için çalışıp çabaladıklarında bunun karşılığını aldıklarına inanırlarsa kendilerini daha mutlu hissederler ve daha fazla çaba harcayabilirler. Aksi durumda bu kadar çok çaba harcayıp ta hiç çaba harcamayanlarla veya aynı çabayı harcayıp ta diğerlerinin daha fazla hak elde ettiklerine inanırlarsa kendilerini örgütten geri çekebilirler ve mutsuz olabilirler. Öğretmenlerin benzer işleri yaptıkları halde kendilerini diğer öğretmenlerle kıyasladıklarında onlardan daha az kazanım elde ettiklerinde bir yoksunluk yaşayabilirler. Öğretmenlerin çalıştıkları kurumlarda yoksunluk yaşadıklarını düşündüklerinde ise örgütün tüm paydaşları bu durumdan olumsuz etkilenecektir. Özellikle öğretmen çalıştığ1 kurumda hak ettiğini düşündüğü karşılığı alamadığında ve bunu başaklarıyla karşılaştırdığında göreceli(göreli) bir yoksunluk yaşayabilir ve bunun sonucunda da kızgınlık öfke, kırgınlık, örgütten uzaklaşma, yabancılaşma vb. duygular içine girebilir. Bu noktada göreceli yoksunluk kavramının açıklanmasında yarar vardır.

\section{Göreceli Yoksunluk Kavramı}

Genelde olumsuz duygu ve düşüncelerin ortaya çıkmasına neden olan göreceli yoksunluk kavramını Crosby (1976), kişinin bir referans düzeyine göre hak edilmiş bir sonuçtan yoksun bırakıldığı inancından kaynaklanan kızgınlık duyguları olarak ifade etmektedir. Walker ve Pettigrew, 1984; Yılmaz, 2019) bireylerin kendilerini başkalarıla, önceki durumlarıyla ya da kendi grubunu başka gruplarla kıyaslaması sonucunda kendisinin ve grubunun hak ettiği yerde olmadığına inanması sonucunda ortaya çıkan, öfke, kırgınlık, kızgınlık, küskünlük ve hoşnutsuzluk durumu olarak ifade etmektedir. Toplu (2010) bireyin kendi aldığı kaynak ve ödüllerle başkalarının aldığı kaynak ve ödülleri karşılaştırması sonucunda kendi aleyhine bir olumsuzluk varsa bireyin yoksunluk hissine kapıldığını ifade etmektedir. Belirtilen tanımlar ve açıklamalardan da anlaşılacağı üzere bir kişi veya grubun kendileriyle benzer işi yaptıkları halde bu konuda olması gerekenlerden mahrum bırakıldıkları duygusunun yaşanması sonucu ortaya çıan göreceli yoksunluk aslında daha çok olumsuz duygu durumlarının ortaya çıkmasına neden olmaktadır. 
İlk olarak, II. Dünya Savaşı'nın ardından, Amerikan askerlerinin kendilerini diğer asker gruplarıyla karşılaştırmaları sonucu ortaya çıkan kavramın (Özkan,2018) örgütler için her geçen gün önemi artmaktadır. Stouffer ve meslektaşları (1949) tarafından Amerikan askerleri ile yapılan çalışmalarla başlayan kuramsal boyut, Davis (1959) tarafından gruplar arası bir karşılaştırmanın sonucu olarak ortaya konmuştur. Bu teori, arzulanan bir mal veya fırsattan (X) yoksun olan bir kişinin, bu kişi benzerlerinin X'e sahip olduğunu algıladığında bir adaletsizlik duygusu yaşadığı mantığ üç unsurun olduğunu belirten Davis(1959); 1) benzer diğerinin X'e sahip olduğunu algılama; 2) X'i istemek ve 3) $X$ almaya hakkınız olduğunu hissetmek olarak açıklamıştır. Bu çalışmaların ortaya koyduğu sonuçlar da daha sonra Runciman'ın göreceli yoksunluk teorisine önemli katkılar sunmuştur. Runciman (1966) göreceli yoksunluk kavraminı üç boyutta tanımlamaktadır: egoist (kişisel) göreceli yoksunluk, kardeşçe (grup) göreceli yoksunluk ve çifte yoksunluk (hem kişisel hem de grup). Bu durumda göreceli yoksunluk kavramını bireylerin kişisel mi, ait olduğu grupla mı, yoksa her ikisiyle de ilişkili olarak mı yaşadıklarına karar verebilirler. Bu konuda yapılan çalışmalar kavramın her geçen gün daha iyi anlaşılmasına katkı sunmuştur. İlerleyen yıllarda Gurr (1970) yapılan çalışmalara katılmış, üç yoksunluk modelinin olduğunu ortaya koymuş, bunları da istek uyandıran yoksunluk, azalan yoksunluk ve aşamalı yoksunluk biçiminde ifade etmiştir. Bu kavramın ortaya çıkmasında büyük emeği geçen Crosby $(1976,1979)$ göreceli yoksunluk kavramını sadece bir algı olarak değil aynı zamanda bir duygu olarak ta açıkça tanımlamış ve bir tür kızgınlık veya şikâyet duygusu ile eşanlamlı olan bir tür öfke anlamında hissedilen yoksunluk olarak ifade etmiştir (Karaçay 2020).

Yukarıdaki açıklamalardan da anlaşılacağı üzere göreceli yoksunluğun, birey ve grup olarak olabileceği gibi her ikisinin birlikte olabileceği de vurgulanmaktadır. Crosby'ye (1976) göre, ön koşullar göreceli yoksunluğun temel unsurlarını oluşturmaktadır. Bir bireyde kişisel göreceli yoksunluk durumunun oluşabilmesi için gerekli beş önemli önkoşul bulunmaktadır. Bunlar ise; (1) herhangi bir şeyi isteme; (2) kendini o şeye sahip olan başkalarıyla karşılaştırma; (3) istenen şeyi hak ettiğini düşünme; (4) o şeye sahip olmanın mümkün olduğunu düşünme ve (5) istenen şeye sahip olamama durumunda kendini suçlu hissetmeme. Özdemir (2019) bu beş önkoşulun, göreceli yoksunluğu algısal süreçler ve öznel değerlendirmelerle şekillenen bilişsel ve adalet-temelli duygusal boyutlardan oluştuğunu ifade etmektedir. Turley (2002) göre, göreceli yoksunluk, bir kişinin memnuniyet duygusuna ve nesnel koşullarına değil, öznel algılarına ve karşılaştırmalarına bağlıdır. Alain (1985) de göreceli yoksunluğu, mutlak ölçütlerden çok göreceli ölçütlere bağlamaktadır. Yine göreceli yoksunluk kavramının temeli aynı zamanda toplumsal karşılaştırmalara da bağlıdır. Bireyler kendilerini diğerleriyle karşılaştırarak toplumsal düzendeki konumlarını değerlendirirler. Bireyin kendisini dâhil olduğu grupla kıyaslaması sonucunda ortaya çıkan yoksunluk, "kişisel yoksunluk"; dâhil olduğu grubu diğer gruplarla kıyaslaması sonucu yaşadığı yoksunluk ise "grup göreceli yoksunluk" olarak sinıflandırılmaktadır. Her iki yoksunluk durumunun altında da benzer şeylerin yattığını söylemek mümkündür. Eğitim örgütleri açısından bakıldığında da öğretmenlerin bu yoksunlukları yaşamasının altında benzer nedenler olabilmektedir.

\section{Göreceli yoksunluğun nedenleri}

Eğitim örgütlerini diğer pek çok örgütlerden farkı kılan girdisinin ve çıktısının insan olmasıdır. Bu nedenle her yönüyle donanımlı ve nitelikli insan yetiştirmek için nitelikli bir 
eğitim verilmesi gerekir. Bu eğitimin verilmesinde de yöneticiler ve öğretmenler önemli bir yer tutar. Yönetici ve öğretmenlerin birlikte çalışması işbirliği yapması eğitim hedeflerinin gerçekleştirilmesi için çok önemlidir. Ancak bazı durumlarda eğitim sistemin kendisinden ve bazen de yöneticilerden kaynaklı öğretmenlerde çeşitli hoşnutsuzluklar yaşanabilmektedir. Bu hoşnutsuzlukların kaynağının nedenleri ise daha çok yönetici tutum ve davranışlarından kaynaklanmaktadır. Bunların başında ise okul müdürlerinin otoriter tutum ve davranışı (İnandı, Tunç, Gılıç,2013), örgütsel güven duygusunun tam olarak oluşturulamaması (Kars, İnand1,2018), okuldaki adalet duygusunun oluşturulamaması, öğretmenlerin yıldırma davranışlarına maruz kalması (Peker, İnandı, Gılıç,2018) gibi nedenleri sıralamak mümkündür. Öğretmenlerin rahatsız olduğu bu davranışları daha da özele indirdiğimizde, özellikle okul müdürlerinin ders dağıtımında taraf tutması, kıt olan kaynak kullanımını sürekli olarak aynı kişiler lehine kullandırması, haftalık ders dağıtımında belirli kişilerin ders programlarını onların isteklerine göre düzenleyip diğer öğretmenlerin istek ve beklentilerini göz ardı etmesi öğretmenlerin göreceli yoksunluk yaşamalarına neden olabilmektedir. Yine öğretmenlerin ailevi sorunlarında istenen izinlerin verilmemesi, sağlık sorunlarının sürekli olarak göz ardı edilmesi, kendini ilgilendiren karar süreçlerine katmaması, okullarda sürekli olarak dezavantajlı sınıfların belirli kişilere verilmesi, başarılı diye adlandırılan sınıfların aynı kişilere verilmesi, bazen hak etmedikleri halde bazı öğretmenlerin yönetime yakın oldukları için ödüllendirilmesi öğretmenlerin kendilerini bu öğretmenlerle kıyaslamalarına neden olabilmektedir. Çok çalıştığı halde hak ettiği saygıyı göremeyen öğretmenlerin kendilerini diğer öğretmenlerle kıyaslaması ve ben bunları yaptığım halde hiçbir önemi olmuyor ve yine diğer öğretmenler saygı ve itibar görüyorlar düşüncesine kapılmalarına neden olabilmektedir. Alan yazında incelendiğinde bu durumu destekleyen çalışmaların olduğu görülmektedir. Baş ve Şentürk (2011) çalışanların yöneticilere karşı adalet algısının bozulması, okula adanmışlıklarını ve yöneticiye karşı güveni olumsuz yönde etkilemektedir. Öğretmenler karar verme süreçlerinin adil olmadığına inandıklarında, işverenlerine bağlılıkları, performansları ve yardımseverlikleri daha az olmakta; iş değiştirme istekleri daha fazla olmaktadır (Polat, 2007). Özgenel, Aktaş (2020) araştırmalarında okul müdürlerin otokratik liderlik stili ile öğretmen performansı arasında negatif yönlü ve düşük ilişki tespit etmişlerdir. İnandı, Uzun ve Yeşil (2016) tarafından yapılan araştırmada; demokratik liderlik stilinin öğretmenlerin üretkenliği ve performansını arttırdı ̆̆ı, otokratik liderlik stilinin ise öğretmen performansına negatif etki ettiği sonucuna ulaşılmıştır. Göksoy (2014) okullarda karara katılım ile ilgili yaptığı araştırmasında öğretmenlerin kendilerini ilgilendiren konularda kararlara ya hiç katılamadıklarını ya da çok az katıldıklarını ortaya koymuştur. Eğitim örgütlerinde demokratik yönetim anlayışlından uzaklaşılıp, otokritik yönetim anlayışına doğru yönelindiğinde, çalışanların yabancılaşma ve tükenmişlik ihtimallerinin daha fazla olabileceği söylenebilir. Çelebi, Vuranok ve Turgut (2015), öğretmenlerin ödül sistemine ilişkin görüşlerini incelemek için yaptıkları bir araştırmada öğretmenlerin ödüllerin adil ve şeffaf olmayan şekilde dağıtıldığını ve ödül almada idareye yakın olmanın etkili olduğunu düşündüklerini ortaya koymuştur. Bu kıyaslamalar sonucunda öğretmenlerin, bazılarının nesnel, bazılarının nesnel olmayan bir şekilde göreceli yoksunluk duygusuna kapılabilecekleri söylenebilir. Bu yoksunluk duygusu da öğretmenlerde çok değişik sonuçların ortaya çıkmasına neden olabilmektedir. Bu noktada göreceli yoksunluk yaşayan çalışanlarda ne tür sonuçlar ortaya çıkmakta çalışmanın amacı açısından önemli görülmektedir. 


\section{Göreceli yoksunluğun sonuçları}

Hangi örgüt olursa olsun göreceli yoksunluğun bireysel ve grup olmak üzere iki şekilde karşımıza çıktığına şahit olmaktayız. Birey düzeyinde yoksun kişiler depresyon, kaygı, utanç ve stres gibi belirtileri daha çok göstermektedir (Walker ve Mann, 1987). Yine işe devamsızlık, düşük öznel iyilik hali, artan stres semptomları ve kötü fiziksel sağlık (Suh ve Flores, 2017). Diğer taraftan, grup düzeyinde göreceli yoksunluk ise kolektif eylem, protesto ve sosyal değişim gibi grup-temelli durumları açıklamaktadır (Walker ve Man, 1987). Yapılan bazı çalışmaların bulgularına bakıldığında (Walker 1999, Schmitt ve ark. 2010; Osborne ve Sibley 2013), kişiler-arası kıyaslamalara dayanan birey düzeyinde göreceli yoksunluğun yaşam doyumu, öz-saygı ve olumlu duygu durumu değişkenleriyle negatif yönde ilişkiler gösterdiğini ortaya koymuşlardır. Bir başka ifade ile göreceli yoksunluk yaşayan kişilerin yaşam doyumları, özsaygı ve olumlu duygu durumlarında bir azalma meydana gelmektedir. Grup göreceli yoksunluk, artan önyargı ve kaynakların dağılımını değiştirmek için toplu eylemde bulunma isteği gibi gruplar arası tutumlara neden olabilmektedir (Toizer, 2016). Bireysel göreceli yoksunluk, kolektif göreceli yoksunluk ile benzer biçimde, sistemi değiştirmeye dönük kolektif davranışlara da yol açabilmekte (Özkan, 2018), sonuç olarak ister bireysel ister grup düzeyinde olsun göreceli yoksunluğun yaşandı̆̆ 1 durumlar hem bireye hem de örgüte olumsuz yansıyabilmektedir. Eğitim örgütleri açısından da durum böyledir. $\mathrm{Bu}$ olumsuzluklar sağlıklı bir şekilde yönetilmezse yıkıcı olan yani fonksiyonel olmayan çatışmaların çıkmasına kadar gidebilmektedir. Etkili yönetildiğinde, okulların ve eğitimcilerin gelişimi ve değişimi için fırsata dönüşebilirken (İnandı, Tunç, Gündüz,2013), kötü yönetildiğinde ise çalışanlarda stres ve öfkeye neden olmaktadır (Gündüz, Tunç, İnandı,2013). Yine öğretmenlerin yabancılaşma yaşamasına neden olabilmektedir. Yabancılaşma, sadece bireysel düzeyde değil, toplumsal, kültürel, siyasal ve örgütsel düzeyde temel bazı etkiler yaratmaktadır (Elma, 2003). Bu süreçte insan giderek ilişkilerinin, eylemlerinin öznesi olmaktan çıkar, nesneleşir (Erjem, 2005). Yabancılaşma yaşayan bireyler çoğunlukla kendilerini başkalarından soyutlayarak örgüt içinde yalnız ve güçsüz hissetmektedirler. $\mathrm{Bu}$ durumda olan öğretmeninde okula ve kendisine pek faydası olmaz. Yine yabancılaşma ve tükenmişlik yaşayan öğretmenlerin iş doyumlarında düşme meydana gelebilmekte (İnandı, Ağgün, Atik, 2010), bu da hem öğretmenin hem de okulun başarısız olmasına neden olabilmektedir. Sonuç olarak bütün bunlar mesleği insan yetiştirmek olan öğretmenlerin motivasyonunu kaybetmesine ve tükenmişlik yaşamalarına neden olmakta bu da eğitim açısından telafi edilemez sonuçlar doğurabilmektedir (Dirican ve Özler, 2014). Son olarak yoksunluk yaşayan öğretmenlerin olumsuz sonuçları sadece okula, öğrenciye ve çevreye değil kendi kişisel gelişimine de olumsuz yansıyacaktır. Yoksunluk yaşadığını düşünen öğretmenin çalışma isteğinin olmayacağı, kariyer hedeflerinden vazgeçebileceği, çocuklara ve okula karşı istekli olmayacağı açıktır. Bu nedenle öğretmenlerin göreceli yoksunluk yaşamaması için yöneticilerin çok büyük çabalar harcamaları gerekmektedir.

Hangi örgüt olursa olsun yoksunluk fikri toplumsal karşılaştırma, toplumsal kimlik, adalet, eşitlik ve sosyal psikoloji gibi pek çok alanda kendini göstermektedir. Ülkemizde Göreceli yoksunluk konusunda yapılan çalışmaların çok az olduğu ve bu çalışmaların daha çok iktisat, sosyoloji, psikoloji ve kadınların yaşadıkları yoksunluk alanlarına ilişkin olduğu görülmektedir (Özkan, 2018; Yürür, 2008; İçerli, 2010; Karaçay, 2020; Özdemir, 2019; Kıral, 2009; Yılmaz, 2019; Toplu, 2010). Ayrıca ilgili alan yazın incelendiğinde öğretmenler açısından göreceli yoksunluk kavramının çalışılmadığ görülmüştür. Bu doğrultuda öğretmenlerde 
göreceli yoksunluk düzeyini, geçerli ve güvenilir bir şekilde ölçecek ve Türk örneklemini yansıtacak bir ölçek geliştirilmesi amaçlanmıştır.

\section{Yöntem}

\section{Araştırmanın Türü}

$\mathrm{Bu}$ araştırma öğretmenlerin göreceli yoksunluk algılarını ortaya koymaya yönelik bir ölçek geliştirme çalışmasıdır. Ölçek geliştirme aşamasında, bireyleri maddelere verdiği tepkilere dayalı olarak ölçek üzerinde yerleştiren (Crocker ve Algina, 1986; Tezbaşaran, 2004) dereceli toplamlar yoluyla ölçekleme yaklaşımı kullanılmıştır.

\section{Çalışma Grubu}

Bu araştırmanın çalışma grubu Mili Eğitim Bakanlığı'na bağlı devlet ve özel okullarda çalışan 427 öğretmenden oluşmuştur. Bu araştırma kapsamında ölçme aracı geliştirme sürecinde kullanılacak olan istatiksel analizlerin gereği olarak ulaşılan çalışma grubunun yeterli büyüklükte olduğu sonucuna ulaşılmıştır (Tabachnick ve Fidell, 2015). Açımlayıcı faktörü analizi için ulaşılan 427 katılımcının, 254"ü $(\% 59,6)$ kadın ve 173"ü $(\% 40,9)$ erkektir. Katılımcıların yaş aralığı 22 ile 50 arasında değişmektedir.

Ölçeğin yapı geçerliğine kanıt sağlayabilmek için açımlayıcı faktör analizinin yürütüldüğü çalışma grubunun dışında DFA için toplamda 457 farklı öğretmene ulaşılmıştır. Sayıltıların testinin ardından 443 gözlem ile Doğrulayıcı Faktör analizi yürütülmüştür.

\section{Ölçek Geliştirme Süreci}

Göreceli yoksunluk düzeyini ölçmek amacıyla geliştirmesi planlanan ölçme aracının geliştirilme sürecinde sırasıyla madde havuzu ve deneme formu oluşturulmuş, deneme formu uygulanmış ve geçerlilik/güvenirlik çalışmaları yapılmıştır. Ölçek maddelerinin yazılması ve denemelik formun oluşturulması sürecinde öncelikli olarak göreceli yoksunluk ile ilgili alan yazın incelenmiş (Alain,1985; Crosby,1976; Crosby,1982; Davis, 1959; Gurr,1970; İçerli,2010; Karaçay,2020; Kıral,2009; Osborne,2015; Özdemir,2019; Özkan,2018; Polat,2007; Runciman1966; Runciman1996; Schmitt, Maes ve Widman, 2010; Suh,Flower, 2017; Toizer, 2016; Turley, 2002; Walker, 1999; Walker ve Mann, 1987; Walker ve Pettigrew, 1984; Y1lmaz, 2019 ) ve araştırmacılar tarafından göreceli yoksunluğa ilişkin olumlu ve olumsuz olmak üzere toplam 46 maddelik bir madde havuzu oluşturulmuştur. Bu maddeler 5'li likert tipine uygun olarak düzenlenmiştir (5:Kesinlikle Katılıyorum, 4:Katılıyorum, 3:Kararsızım, 2:Katılmıyorum, 1:Kesinlikle Katılmıyorum). Ölçek geliştirme süreci dikkate alınarak yazılan maddeler uzman görüşlerine sunularak kapsam geçerlik indeksleri hesaplanmıştır. Bu amaçla; eğitim bilimleri alanından 7 uzmanın madde bazında ilgililik ve açıklık açısından değerlendirmelerine başvurulmuştur. Kapsam geçerliliğine yönelik olarak alan uzmanlarından maddelerin uygunluğu konusunda görüş belirtmeleri istenmiştir ("1: hiç uygun değil" ile "10: çok uygun" arasında). Değerlendirmeler sonucunda, uzmanlara sunulan değerlendirme formuna ilişkin verilen yanıtlardan yola çıkılarak, düzeltilmiş kappa tekniği kullanılarak madde havuzunda yer alan maddelerin kapsam geçerlik oranları hesaplanmıştır. Kappa istatistiğinin yorumlanmasında Landis ve Koch (1977) tarafından önerilen uyum düzeyleri kullanılmaktadır. Maddelerde .80 değeri ölçüt olarak belirlenmiş olup bu değerin altındaki toplam 15 madde deneme formundan atılmıştır. 4 madde ise dil, imla ve anlatım 
bakımından uzman görüşleri dikkate alınarak düzeltilmiştir. Deneme formunun son hali, atılan maddeler sonucunda 31 maddeden oluşmaktadır. 31 maddelik deneme formu gerekli düzenlemeler yapılarak uygulamaya hazır bir ölçek haline dönüştürülmüştür. Ölçek formunda yer alan 31 maddelik deneme formunda her bir ifade 5'li likert tipi; "Kesinlikle Katılıyorum", "Katılıyorum", "Kararsızım", "Katılmıyorum", "Kesinlikle Katılmıyorum" ölçek ifadeleri ile değerlendirilmesi uygun görülmüştür.

\section{Verilerin Analizi}

Ölçek geliştirme sürecinde ölçeğin yapısını açımlayabilmek ve yapı geçerliği kanıtı üretebilmek amacıyla Açımlayıcı Faktör Analizi (AFA) kullanılmıştır. Faktör analizi, birbiriyle ilişkili çok sayıda değişkeni bir araya getiren ve daha az sayıda, anlamlı yeni değişkenler sunmayı amaçlayan çok değişkenli bir istatistiktir (Büyüköztürk, 2014). Açımlayıcı Fakör Analizi çok değişkenli bir analiz olması sebebiyle toplanan verilerin çok değişkenli analize uygunluğu ile ilgili olarak çeşitli sayıltı analizleri gerçekleştirilmiştir. Ölçek geliştirme sürecinde göreceli yoksunluk açısından ortaya konan yapıyı ortaya koyabilmek amaciyla yapılan açımlayıcı faktör analizinin sayıltılarını test etmek için 427 bireyin ölçme aracına verdiği yanıtlar "Aykırı değerler, tek değişkenli ve çok değişkenli normallik dağılımı, doğrusallık, R'nin faktörlenebilirliği" bakımından incelenmiş, veri AFA için hazır hale getirilmiştir.

Deneme formunun uygulanmasından sonra eksik veri gözlenmediğinden analizde tam veri matrisi kullanılmış olup eksik verilerle ilgili bir işlem yapılmamıştır. 427 gözlemle analizler yapılmıştır. Madde dağılımları, çarpıklık ve basıklık katsayıları incelenmiştir. Tek değişkenli ve çok değişkenli aykırı değerler için sırasıyla $Z$ değerleri ve mahalanobis uzaklıkları incelenmiştir. Hesaplanan $Z$ değeri +4 ile -4 aralığının dışında kalan gözlem olmadığı için veri setinde tek değişkenli aykırı değer bulunmadığı tespit edilmiştir. Hesaplanan mahalanobis büyüklüklerine göre ise; 20 gözlem ölçüt değerin ( $x^{2}$ 31,0001=61.098) üzerinde olması gerekçesiyle analize dahil edilmemiştir. Çoklu bağlantı problemi için tolerans ve VIF değerleri incelenmiş; tolerans değerleri $>0,20$ ve VIF değerleri $<5$ olduğundan hiçbir maddede çoklu bağlantı problemi olmadığ1 görülmüştür. İncelenen Durbin Watson istatistiği 2,019 olarak hesaplanmış ve hataların bağımsız olduğuna (Kalaycı, 2005) karar verilmiştir.

Ölçek geliştirme sürecinde elde edilen 407 gözlem üzerinden verilerin faktör analizi için uygunluğunu tespit etmek için Kaiser-Meyer-Olkin (KMO) testi, Bartlett testi ve antiimage korelâsyonu incelenmiştir. Verilerin analizinde her bir maddenin ortak varyansının .50, faktör yükünün .45 ve iki faktöre birden verilen faktör yükü arasındaki farkın .10'un üzerinde olmasına dikkat edilmiştir (Büyüköztürk, 2011; Tabachnick ve Fidel, 2013). Döndürme tekniğini belirlemek amacıyla faktörler arası ilişkiye bakılmıştır. Faktör analizi sonucunda elde edilen faktör puanları arasındaki ikili ilişkiler, $\mathrm{p}<0,05$ düzeyinde anlamlı olmadığ 1 için (Büyüköztürk, 2011; Tabachnick ve Fidel, 2013) dik döndürme tekniklerinden varyansı maksimum yapan varimax tekniği kullanılmıştır. Faktör yapısına karar verilirken açımlayıcı faktör analizi tekniği işe koşulmuştur. Faktör yükü çalışmada ölçüt olarak kullanılan $0.45^{\prime \prime}$ in altında olan üç madde $(\mathrm{m} 8, \mathrm{~m} 28, \mathrm{~m} 26)$ ve iki faktöre birden verilen faktör yükü arasındaki farkın .10'un üzerinde olan bir madde (m20) analizden çıkarılmıştır. Yanı sıra iki madde ile bir faktör açıklanamayacağı için 6 madde (m9, m18, m24, m27, m29,m30) ölçekten çıkarılmış ve 20 maddelik nihai ölçek formu elde edilmiştir. Açımlayıcı Faktör Analizine ilişkin örneklemin yeterliliği ile verinin faktörlenebilirliğini değerlendirmek üzere Kaiser-Meyer-Olkin (KMO) katsayısı 0,899 olarak hesaplanmıştır. Çalışmada korelasyon matrisine ilişkin olarak Bartlett 
testi anlamlı bulunmuş $\left(x^{2}=2621,311 ; \mathrm{p}<0,01\right)$, dolayısıyla matrisin faktör analizine uygun olduğu anlaşılmıştır.

AFA ile ortaya konulan yapının farklı bir grup üzerinde de benzer yapı gösterip göstermediğini saptamak amacıyla doğrulayıcı faktör analizi (DFA) gerçekleştirilmiştir. DFA ile ek yapı geçerliği elde etme yoluna gidilmiştir. DFA'nın yapılabilmesi için nihai ölçek formu farklı bir grup üzerinde uygulanmış ve toplam 457 öğretmenden veri toplanmıştır. AFA'ya benzer şekilde, DFA da çok değişkenli bir istatistik olduğu için veri seti DFA'ya uygun hale getirilmiştir. Ulaşılan verilerin DFA için uygun olup olmadığını kontrol etmek için sayıltılar kontrol etmiştir. Yeni çalışma grubunda tek değişkenli aykırı değere rastlanmazken; 11 gözlem çoklu aykırı değer olması sebebiyle $x^{2}$ 20;,0001=45.32) gözlem setinden çıkarılmıştır. Kalan 443 verinin çoklu bağlantı problemi için tolerans ve VIF değerlerine bakılmıştır. Maddeler incelendiğinde çoklu bağlantı problemi olmadığı sonucuna ulaşılmıştır. Hataların bağımsızlığ1 için incelenen Durbin Watson istatistiği 1,991 bulunmuştur. Bir veri setinde hesaplanan Durbin Watson istatistiğinin 2'ye yakın değerler alması gerekmektedir (Tabachnick ve Fidell, 2015). Dolayısıyla hatalar birbirinden bağımsızdır. Sayıltılar incelendikten sonra yapılan DFA çalışmasında, ölçeğin üç faktörlü yapısı test edilmiştir. DFA ile modelin geçerliğini ortaya koymak için alan yazında sıklıkla kullanılan bazı uyum indeksleri (ki-kare uyum testi, iyilik uyum indeksi, AGFI, CFI, RMSEA, RMR, SRMR ve NNFI) incelenmiştir (Çokluk, Şekercioğlu ve Büyüköztürk, 2014; Tabachnick ve Fidell, 2015). Yanı sıra gizil değişkenlerin gözlenen değişkeni açıklama durumuna ilişkin standardize yük değerleri ve $t$ değerleri, $t$ değerlerinin anlamlılığı (Çelik ve Yılmaz, 2013) değerlendirilmiştir.

\section{Bulgular}

\subsection{AFA Bulguları:}

Aşağıda verilerin analize hazır hale getirilmesinin ardından yürütülen açımlayıcı faktör analizi sonucu elde edilen ve yapıyı ortaya koyan temel istatistiklere yer verilmiştir. Tablo 1 de faktör sayısını, faktörlerce açıklanan varyans ve toplam varyansı ortaya koyan tablo bulunmaktadır.

Tablo 1. Faktörlerce Açılanan Toplam Varyans

\begin{tabular}{|c|c|c|c|c|c|c|c|c|c|}
\hline \multirow[b]{3}{*}{ Bileşen } & \multicolumn{3}{|c|}{ Başlangıı̧ özdeğerler } & \multicolumn{3}{|c|}{$\begin{array}{l}\text { Karesi alınan yüklerin toplam } \\
\text { çıarımı }\end{array}$} & \multicolumn{2}{|c|}{$\begin{array}{l}\text { Karesi alınan } \\
\text { döndürme toplamı }\end{array}$} & \multirow[t]{2}{*}{ yüklerin } \\
\hline & & Varyans & Birikimli & & & & & & \\
\hline & Toplam & $\%$ & $\%$ & Toplam & Varyans\% & Birikimli\% & Toplam & Varyans\% & Birikimli\% \\
\hline$\overline{1}$ & 6,114 & 30,570 & 30,570 & 6,114 & 30,570 & 30,570 & 5,076 & 25,380 & 25,380 \\
\hline 2 & 2,251 & 11,254 & 41,823 & 2,251 & 11,254 & 41,823 & 2,875 & 14,374 & 39,754 \\
\hline 3 & 1,353 & 6,767 & 48,590 & 1,353 & 6,767 & 48,590 & 1,767 & 8,836 & 48,590 \\
\hline
\end{tabular}

Tablo 1 incelendiğinde, ölçeğin özdeğeri birden büyük olan, toplam değişkenliğin \% 48,59'unu açıklayan üç faktörlü bir yapı elde edilmiştir. Bu üç faktörün özdeğerleri sırasıyla 1.faktör 6,114 , 2.faktör 2,251 ve 3.faktör 1,353 'tür. Bu üç faktörün açkladıkları toplam varyans ise $\% 48,590$ 'dir. 
Sosyal bilimlerde çok faktörlü yapılar için açıklanan toplam varyans için $\% 40$ ile $\% 60$ oranları yeterli kabul edilmektedir (Scherer, Wiebe Luther \& Adams, 1988' den akt., Tavşancıl \& Keser, 2002). Bu faktörlere ilişkin çizilen yamaç eğim grafiği Şekil 1'deki gibidir.

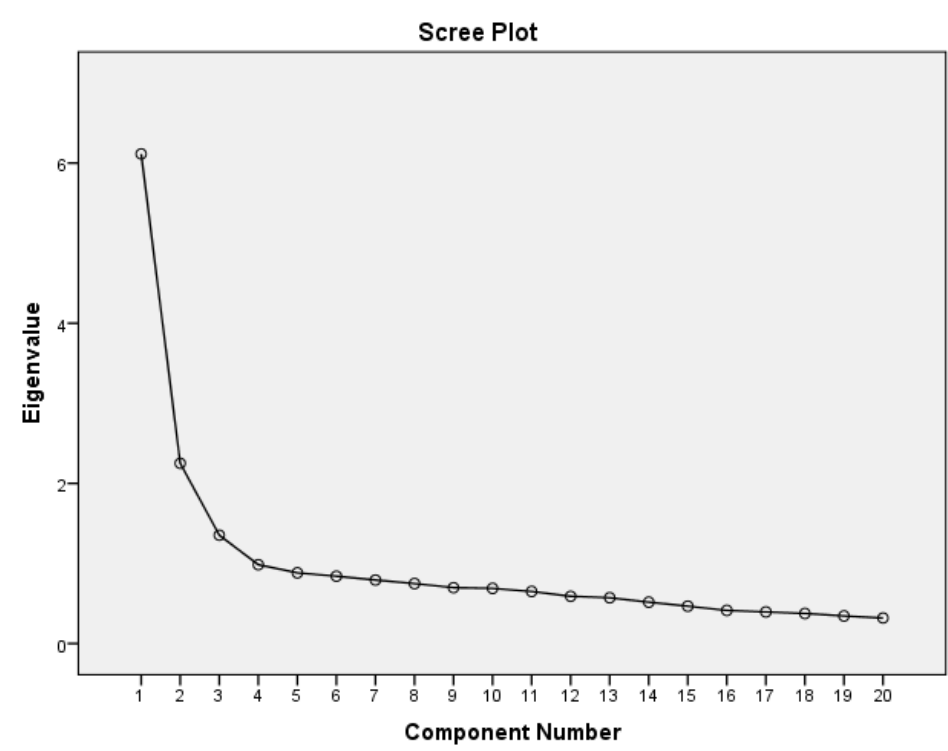

Şekil 1. Faktör Özdeğerlerine İlişkin Yamaç Eğim Grafiği

Şekil 1'deki faktör sayısına karar vermek üzere yamaç eğim grafiği dikkate alındığında ortaya çıkan keskin düşüşlerin 3 faktörlü bir yapıyı gösterdiği ve faktör analizi sonucunda ulaşılan bulgular da bu yapıyı desteklemektedir. Dolayısıyla özdeğeri açıklanan toplam varyans ve yamaç eğim grafiği sonuçları ölçeğin üç faktörlü bir yapıya sahip olduğu bulgularını desteklemektedir. Döndürme sonrası işlemde maddelerin faktörlere verdiği yük ve içerdiği anlamlar doğrultusunda maddeler birbiriyle ilişkilendirilerek faktör isimlendirilmesi yapılmıştır. Birinci boyuta "Yönetimsel Yoksunluk", ikinci boyuta "Kişisel Yoksunluk" ve üçüncü boyuta "Gelişimsel Yoksunluk" isimleri verilmiştir. Maddeler ve bulundukları faktörler, maddelerin bu faktörlere dağılımı ve faktör yükleri aşağıdaki Tablo 2'de yer almaktadir. 
Tablo 2. Dönüştürülmüş Bileşenler Matrisi Ölçekte Yer Alan İfadeler ve Faktör İsimleri

\begin{tabular}{|c|c|c|c|c|c|}
\hline & & $\begin{array}{c}\text { Faktör 1 } \\
\text { Yönetims } \\
\text { el } \\
\text { Yoksunlu } \\
\text { k }\end{array}$ & $\begin{array}{c}\text { Faktör } 2 \\
\text { Kişisel } \\
\text { Yoksunlu } \\
\text { k }\end{array}$ & $\begin{array}{c}\text { Faktör } 3 \\
\text { Gelişims } \\
\text { el } \\
\text { Yoksunl } \\
\text { uk }\end{array}$ & $\begin{array}{c}\text { Ortak } \\
\text { varyans }\end{array}$ \\
\hline m19 & $\begin{array}{l}\text { Müdüre yakın öğretmenler hak etmedikleri } \\
\text { halde itibar görür }\end{array}$ & 765 & & & 629 \\
\hline $\mathrm{m} 18$ & $\begin{array}{l}\text { Müdürüm okul için yaptı̆̆ım çalışmaları } \\
\text { görmezden gelir. }\end{array}$ & 762 & & & 590 \\
\hline $\mathrm{m} 6$ & $\begin{array}{l}\text { Müdürümüz başarılı sınıfları kendine yakın } \\
\text { öğretmenlere vermektedir. }\end{array}$ & 761 & & & 618 \\
\hline $\mathrm{m} 9$ & $\begin{array}{l}\text { Okulumuzda ortak alınan kararlarda müdüre } \\
\text { yakın fikirler kabul görür. }\end{array}$ & 686 & & & ,548 \\
\hline $\mathrm{m} 7$ & $\begin{array}{l}\text { Okulumuzda idari pozisyonlarda yönetime } \\
\text { yakın gruplardan kişiler vardır. }\end{array}$ & 677 & & & ,535 \\
\hline $\mathrm{m} 11$ & Sınıfım için alınan kararlarda benim fikrim alınır. &,- 595 & & &, 383 \\
\hline $\mathrm{m} 3$ & $\begin{array}{l}\text { Haftalık ders programları hazırlarken okul } \\
\text { müdürü bazı öğretmenlere ayrıcalık tanır. }\end{array}$ & ,590 & & & 413 \\
\hline $\mathrm{m} 4$ & $\begin{array}{l}\text { Okul müdürüyle çatışma yaşadığımda açığımın } \\
\text { aranacağı hissine kapılırım. }\end{array}$ & ,588 & & & 495 \\
\hline $\mathrm{m} 5$ & $\begin{array}{l}\text { Çalışma saatlerimde ihtiyaç duyduğumda okul } \\
\text { müdürü bana esneklik göstermez. }\end{array}$ & ,584 & & & 365 \\
\hline $\mathrm{m} 1$ & $\begin{array}{l}\text { Okul müdürü takdir edici tavırlarıyla okulda } \\
\text { önemli biri olduğumu hissettirir. }\end{array}$ &,- 576 & & & 331 \\
\hline $\mathrm{m} 16$ & $\begin{array}{l}\text { Problemli sınıflar diğer öğretmenlere kıyasla } \\
\text { daha çok bana verilmektedir. }\end{array}$ & ,548 & & & 332 \\
\hline m15 & $\begin{array}{l}\text { Aynı okulda çalıştığım arkadaşlarımla rekabet } \\
\text { etmek bende gerginlik yaratır. }\end{array}$ & & 717 & & 489 \\
\hline
\end{tabular}




\begin{tabular}{|c|c|c|c|c|}
\hline & Çalışmalarımın okul müdürü tarafında sürekli & & & \\
\hline $\mathrm{m} 14$ & $\begin{array}{l}\text { diğer öğretmenlerle kıyaslanması beni mutsuz } \\
\text { eder. }\end{array}$ & 687 & &, 547 \\
\hline $\mathrm{m} 17$ & $\begin{array}{l}\text { Okul müdürünün bana karşı haksız davranışları } \\
\text { bende okuldan ayrılma isteği uyandırır. }\end{array}$ & 644 & &, 521 \\
\hline $\mathrm{m} 2$ & $\begin{array}{l}\text { Okul müdürünün çalışmalarımla ilgili olumsuz } \\
\text { eleştirisi beni mutsuz eder. }\end{array}$ & 608 & & 373 \\
\hline $\mathrm{m} 10$ & $\begin{array}{l}\text { Okulumdaki öğrenci başarılarında müdüre yakın } \\
\text { öğretmenlerin ön plana çıkarılması beni kızdırır. }\end{array}$ &, 574 & & ,492 \\
\hline $\mathrm{m} 8$ & $\begin{array}{l}\text { Okul müdürümün nöbet günlerimi ders } \\
\text { programıma uygun yapmaması beni kızdırır. }\end{array}$ &, 527 & & 370 \\
\hline $\mathrm{m} 13$ & $\begin{array}{l}\text { Başarılı sonuçlar almak yeni öğretim yöntemleri } \\
\text { geliştirmemi sağlar }\end{array}$ & & 805 & 656 \\
\hline $\mathrm{m} 12$ & Kendimi sürekli yenileme ihtiyacı duyarım. & & ,716 &, 534 \\
\hline $\mathrm{m} 20$ & $\begin{array}{l}\text { Öğretmenlik becerisine güvendiğim kimselerle } \\
\text { işbirliği yaparım. }\end{array}$ & & ,694 & ,498 \\
\hline
\end{tabular}

Öğretmenlerde Göreceli Yoksunluk Ölçeği'nin 3 faktörlü yapısı görülmektedir. Birinci faktör olan yönetimsel yoksunluk alt faktöründe 11 madde (m1,m3,m4,m5,m6,m7,m9,m11,m16,m18,m19) kişisel yoksunluk alt faktöründe 6 madde (m2,m8,m10,m14,m15,m17), Gelişimsel Yoksunluk alt faktöründe ise 3 madde (m12,m13,m20) bulunmaktadır. Yönetimsel yoksunluk alt faktöründeki maddelerin faktör yükleri ,548 ile, 765 arasında, kişisel yoksunluk alt faktöründeki maddelerin faktör yükleri ,527 ile ,717 arasında, gelişimsel yoksunluk alt faktöründeki maddelerin faktör yükleri ise ,694 ile ,805 arasında değişmektedir. Yine tablonun son sütununda yer alan açılanan ortak varyans değerlerinin 0.330 ile 0.656 aralığında değiştiği; dolayısıyla ölçeğe alınan tüm maddelerin ana yapıdaki değişkenlikte katkısının bulunduğu sonucuna ulaşılmıştır.

Bu araştırmada, ulaşılan 407 gözlem ile ölçeğin nihai formunun güvenirliğine ilişkin Cronbach Alfa güvenirlik katsayıları, toplam test için .78, Yönetimsel Yoksunluk alt boyutu için .72, Kişisel Yoksunluk alt boyutu için .73, Gelişimsel Yoksunluk alt boyutu için .55 olarak hesaplanmıştır. Sonuç olarak, nihai formdan elde edilen iç tutarlık katsayılarının tüm test için ve Yönetimsel ve Kişisel yoksunluk boyutları için kabul edilebilir düzeyde güvenirlik katsayılarına sahip oldukları görülmektedir. Fakat Gelişimsel yoksunluk alt boyutunun kabul edilebilir düzeyde bir iç tutarlılık katsayısına sahip olmadığı görülmektedir. Bunun nedeninin ilgili faktörlerde yer alan madde sayısının azlığından kaynaklandığı düşünülmektedir. Geliştirilen ölçek bu haliyle psikometrik açıdan geçerli ve güvenilir bir ölçme aracı olarak kullanılabilir. 


\subsection{DFA Bulguları}

AFA sonucunda belirlenen yapının geçerliğine kanıt sağlamak amacıyla farklı bireylerden elde edilen veriler üzerinde Doğrulayıcı Faktör Analizi (DFA) çalışması yapılmıştır. Ölçeğin AFA sonucu ortaya çıkarılan yapısının geçerliğini test etmek için (DeVellis, 2016) 443 yeni veri üzerinden gerçekleştirilen doğrulayıcı faktör analizi (DFA) sonucunda elde edilen model, bu modele ait standardize yük değerleri ve t değerleri Şekil 2 ve Şekil 3'te gösterilmiştir.

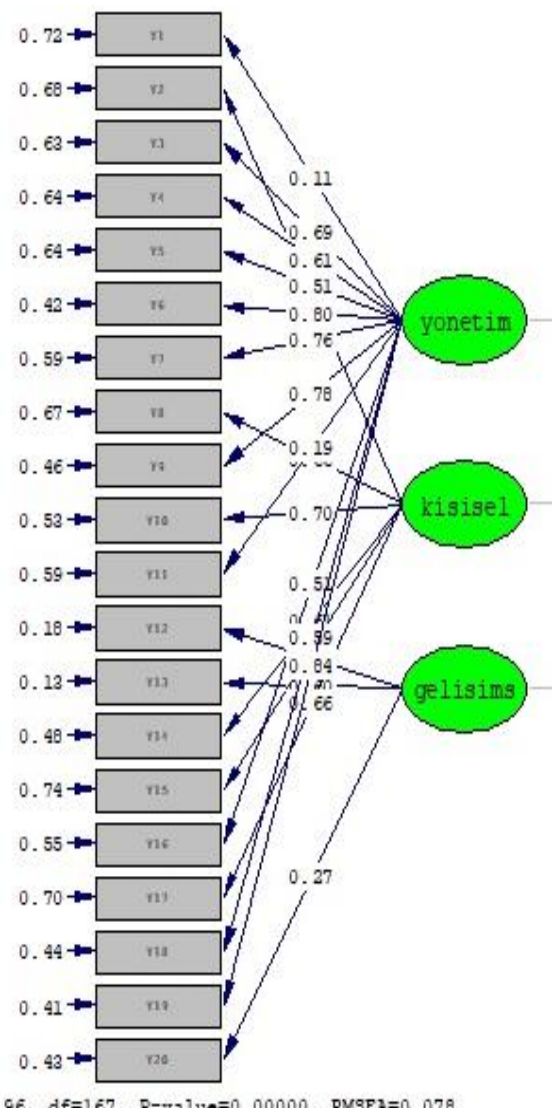

Chi-3quare $=620.96, d f=167, \mathrm{P}-\mathrm{value}=0.00000, \mathrm{RMSEA}=0.078$

Şekil 2. DFA Sonucunda Elde Edilen Standardize Yük Değerleri

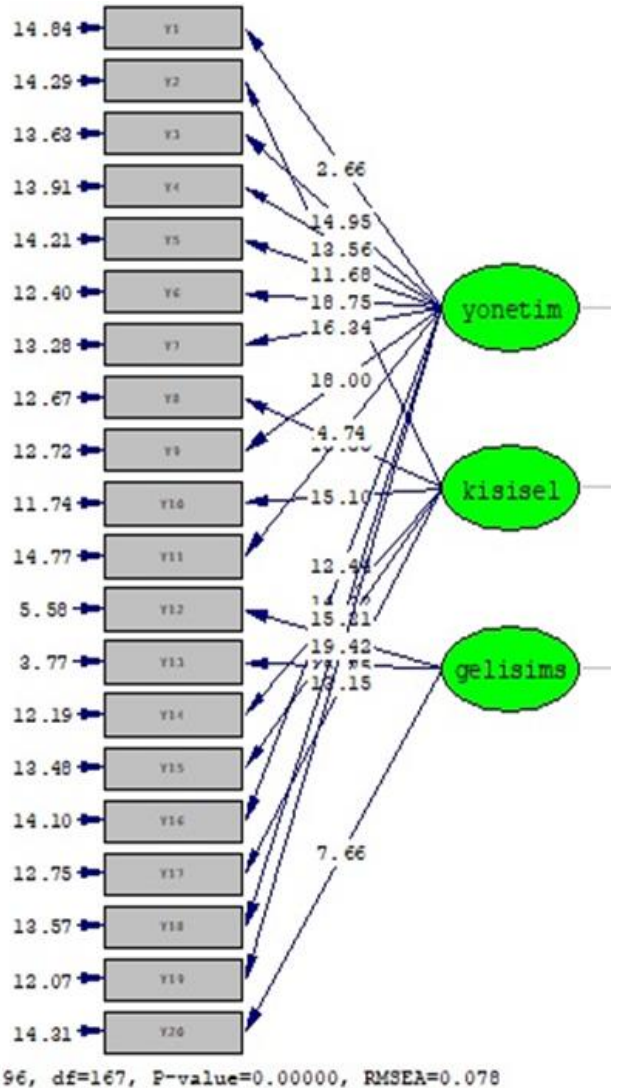

Chi-9quare $=620.96, \mathrm{df}=167, \mathrm{p}-\mathrm{value}=0.00000, \mathrm{RM} E \mathrm{E}=0.078$

Şekil 3. DFA Sonucunda Elde Edilen $t$ Değerleri

Gizil değişkenlerin gözlenen değişkeni açılama durumuna ilişkin standardize yükler ve t değerleri oklar üzerinde gösterilmiştir. Yapılan analizler sonucunda, Şekil 2'de verilen DFA modelindeki tüm faktör standardize yük değerleri ve $t$ değerlerinin istatistiksel olarak anlamlı olduğu belirlenmiştir $(p<0,01)$. Parametre tahminleri, eğer $t$ değerleri 1,96 y $y$ aşarsa 0,05 düzeyinde ve 2,56'yı aşarsa 0,01 düzeyinde anlamlıdır (Çelik ve Yılmaz, 2013). Bu çerçevede şekil incelendiğinde örtük değişkenlerden gözlenen değişkenlere giden yollara ait t değerlerin 0,01 düzeyinde anlamlı olduğu görülmüştür. Test edilen ölçme modeline ilişkin uyum 
indeksleri ve bu indeksler için kabul edilen değerlendirme ölçütleri (Çokluk, Şekercioğlu ve Büyüköztürk, 2014; Tabachnick ve Fidell, 2015) Tablo 4'te yer almaktadır.

Tablo 4. Ölçme Modeline İlişkin Uyum İndeksleri ve Bu İndeksler için Kabul Edilen Değerlendirme Ölçütleri

\begin{tabular}{llll}
\hline İndeks & İyi uyum değeri & $\begin{array}{l}\text { Kabul edilebilir } \\
\text { değer }\end{array}$ & Hesaplanan değer \\
\hline$\chi 2$ p değeri & $\mathrm{p}>0,05$ & - & - \\
$\chi 2 /$ sd & $<2$ & $<5$ & $620,96 / 167=3,46$ \\
GFI & $>0,95$ & $>0,90$ & 0,88 \\
AGFI & $>0,95$ & $>0,90$ & 0,85 \\
CFI & $>0,95$ & $>0,90$ & 0,94 \\
RMSEA & $<0,05$ & $<0,10$ & 0,078 \\
RMR & $<0,05$ & $<0,10$ & 0,064 \\
SRMR & $<0,05$ & $<0,08$ & 0,081 \\
NNFI & $0,00-1,00$ arasi & - & 0,93 \\
\hline
\end{tabular}

Tablo 4 incelendiğinde hesaplanan değerler, iyi uyum değeri ya da kabul edilebilir değer sınırları içerisinde kalmaktadır (Kline, 2005; Tabachnick ve Fidell, 2015). Bu bulgu model uyumunun sağlandığını ortaya koymaktadır. $x^{2}=1172,07 \quad(\mathrm{sd}=167)$ istatistiğinin anlamlı olduğu $(\mathrm{p}<0,05)$ gözlenmiştir ve $x^{2} / \mathrm{sd}=3.46$ olarak hesaplanmıştır. Elde edilen bu değer, modelin kabul edilebilir bir uyum iyiliğine sahip olduğunu göstermektedir.

\section{Sonuç ve Öneriler}

$\mathrm{Bu}$ çalışmanın amacı, öğretmenlerin göreceli yoksunluk algılarını ölçebilecek geçerli ve güvenilir bir ölçme aracı geliştirmektir. Elde edilen bulgular doğrultusunda yönetimsel yoksunluk, kişisel yoksunluk ve gelişimsel yoksunluk olmak üzere 3 alt boyuttan oluşan toplam 20 maddelik bir ölçek geliştirilmiştir. Yönetimsel yoksunluk boyutu, öğretmenlerin okul yönetimiyle ilgili yaşadıkları yoksunluk algısı ile ilgili olup toplam 11 maddeden oluşmaktadır. Kişisel yoksunluk boyutu öğretmenlerin kendilerini diğer öğretmenlerle kıyaslaması sonucu yaşadıkları yoksunluk algısı olup 6 maddeden oluşmaktadır. Gelişimsel yoksunluk boyutu, öğretmenlerin mesleki gelişimleri ile ilgili yaşadıkları yoksunluk algısı ile ilgili olup 3 maddeden oluşmaktadır. Bu üç boyutun açıkladı̆̆ 1 toplam varyans ise \%48,6 olarak elde edilmiştir. Ölçmeye konu olan "göreceli yoksunluk"taki değişimin neredeyse yarısı ölçekte bulunan maddeler ve bu maddelerden oluşan faktörlerle açıklanabilmektedir. Elde edilen güvenirlik ve geçerlik bulguları dikkate alındığında geliştirilen ölçeğin öğretmenlerde göreceli yoksunluk düzeyini ölçmek amacıyla kullanılabilecek psikometrik nitelikler bakımından güçlü bir ölçme aracı olduğunu göstermiştir.

Öğretmenlerde Göreceli Yoksunluk Ölçeği öğretmenlerin yoksunluk algılarını ölçmek amacıyla önemli bilgiler sağlamasının yanında bazı sınırlılıklara sahiptir. Türk örneklemini 
daha iyi yansıtması ve çalışmanın genellenebilirliğini arttırmak için gelecekte daha farklı çalışma grupları ile çalışmalar tasarlanabilir. Öğretmenlerde göreceli yoksunluk kavramının kuramsal temellerinin güçlendirilmesi açısından, geliştirilen bu ölçeğin aracı olduğu farklı alt gruplarda (cinsiyet, kıdem, okulun bulunduğu bölge... vb.) hipotez çalışmalarının yapılması önerilebilir. Sonuç olarak, öğretmenlerin yoksunluk algılarını hem kendileri hem de toplum açısından önemi göz önüne alındığında, geliştirilen Öğretmenlerde Göreceli Yoksunluk Ölçeğinin Türk örneklemine uygun geçerli ve güvenilir bir şekilde ölçebileceği ve literatüre önemli bir katkı sağlayacağı düşünülmektedir. 


\section{Kaynakça}

Alain, M. (1985). Göreceli yoksunluğun ampirik bir doğrulaması. İnsan İlişkileri, 38 (8), $\quad 739-$ 749.

Baş, G., ve Şentürk, C. (2011), İlköğretim okulu öğretmenlerinin örgütsel adalet, örgütsel vatandaşlık ve örgütsel güven algıları. Kuram ve Uygulamada Ĕ̆itim Yönetimi, 17(1), 29-62

Büyüköztürk, Ş. (2014). Deneysel desenler: Öntest-sontest, kontrol grubu, desen ve veri analizi. Ankara: Pegem A.

Crosby, F. A. (1976). A model of egoistical relative deprivation. Psychological Review,83, 85113.ayın Dağıtım

Crosby, F. A. (1982). Relative deprivation and working women. New York: Oxford University Press.

Çelebi, N., Vuranok, T. ve Turgut, I. (2015). İlk ve ortaokullarda öğretmenlerin ödül sistemine ilişkin görüşleri. Mehmet Akif Ersoy Üniversitesi Ĕ̆itim Fakültesi Dergisi, 1(34), 75-104

Çelik, H. E. ve Yılmaz, V. (2013). Lisrel 9.1 ile yapısal eşitlik modellemesi. Ankara: Anı Yayıncılık.

Çokluk, Ö., Şekercioğlu, G. ve Büyüköztürk, Ş. (2018). Çok Değişkenli İstatistik SPSS ve LISREL Uygulamaları. (5. Bask1). Ankara: Pegem Akademi Yayınları.

Davis, J. A. (1959). A formal interpretation of the theory of relative deprivation. Sociometry, 22, 280-296.

DeVellis, R. F. (2016). Ölçek geliştirme kuram ve uygulamalar. (T. Totan, Çev. Edt.). Ankara: Nobel Yayınları

Dirican, M. Ö. ve Özler, N. D. (2014). Örgütlerde yabancılaşma ile tükenmişlik sendromu arasındaki ilişkiyi belirlemeye yönelik bir araştırma. Dumlupınar Üniversitesi Sosyal Bilimler Dergisi, 39, 291-310.

Elma, C. (2003). Illköğretim okulu öğretmenlerinin işe yabancılaşması (ankara ili örneği). Yayımlanmamış Doktora Tezi. Ankara Üniversitesi, Eğitim Bilimleri Enstitüsü, Ankara.

Erjem, Y. (2005). Eğitimde yabancılaşma olgusu ve öğretmen: Lise öğretmenleri üzerine sosyolojik bir araştırma. Türk Ĕ̆itim Bilimleri Dergisi,3(4), 395-417.

Göksoy, S. (2014). Okul yönetiminde karara katılım. Abant İzzet Baysal Üniversitesi Eğitim Fakültesi Dergisi, 14(2), 253-268

Gurr, T. R. (1970). Why men rebel. Princeton, N.J.: Princeton University Press.

Gündüz B, Tunç B, İnandı Y, (2013). Okul yöneticilerinin öfke ve stresle başa çıma yaklaşımları ile çatışma yönetimi stilleri arasındaki ilişki. International Journal of Human Sciences, 10(1): 641-660.

İçerli, L. (2010). Örgütsel adalet: kuramsal bir yaklaşım. Aksaray Üniversitesi İİBF İşletme Bölümü İnandı, Y., Ağgün, N. ve Atik, Ü. (2010). Yönetici ve Öğretmenlerin Görüşlerine Göre İlköğretim Okullarında Çalışan Öğretmenlerin İş Doyum Düzeyleri. Mersin Üniversitesi Ĕ̈itim Fakültesi Dergisi, 6(1), 102-126.

İnand1, Y., Tunç, B. ve Gılıç, F. (2013). School administrators leadership styles and resistance to change. International Journal of Academic Research Part B, 5(5), 196-203.

İnand1, Y., Uzun, A. ve Yeşil, H. (2016). The Relationship Between Principals' Leadership Styles and Their Efficacy in Change Management. Journal of Educational Sciences Research, 6 (1), 191- 209.

Kalayc1, Şeref (2005) SPSS Uygulmalı Çok Değişkenli İstatistik Teknikleri, Ankara: Asil Yayın Dağıtım 
Karaçay, G . (2020). Leader-Member Exchange and In-Role Performance: Can Perceived Organizational Support be a Remedy for Employee Affective Reaction? . Optimum Ekonomi ve Yönetim Bilimleri Dergisi , 7 (2) , 361-372 . DOI: 10.17541/optimum.661529

Kars, M., İnand1, Y. (2018). Relationship between school pricipals' leadership behaviours and teachers' organizational trust. Eurasian Journal of Educational Research, 74, 145-164. Retrieved from: https://dergipark.org.tr/tr/download/article-file/625731

Kıral, G. (2009). Türkiye'de yasayan kadınların göreli yoksunluk ve adil dünya inancı ile siyasal katılım düzeyleri arasındaki ilişki. Yüksek Lisans Tezi. Ankara Üniversitesi Sosyal Bilimler Enstitüsü.

Kline, R. B. (2005). Principles and Practice of Structural Equation Modeling. (2nd edition). New York: Guilford Publications, Inc.

Landis, J, R., \& Koch, G. (1977). The measurement of observer agreement for categorical data. Biometrics, 33, 159-174

Osborne D, Sibley CG (2013) Through rose-colored glasses: System-justifying beliefs dampen the effects of relative deprivation on well-being and political mobilization. Pers Soc Psychol Bull, 39:991-1004

Osborne, D. (2015). Göreceli Yoksunluk. Uluslararası Siyasal İletişim Ansiklopedisi, 1-5.

Özdemir, F. (2019). Farklı göreli yoksunluk seviyelerinde başa çıkma stratejileri ve öznel oluş arasındaki ilişki. Psikiyatride Güncel Yaklaşımlar, Cilt: 11 Sayı: Ek 1 (Araştırma Sayısı), 234245. DOI: 10.18863 / pgy.616916

Özgenel, M., \& Aktaş, A. (2020). Okul müdürlerinin liderlik stillerinin öğretmen performansına etkisi. Uluslararası Liderlik Çalışmaları Dergisi: Kuram ve Uygulama, 3(2), 1-18.

Özkan, Ü. (2018). Farklı lider üye ve ekip üye etkileşim kalitesi kombinasyonlarının göreceli yoksunluk ve psikolojik sermaye bağlamında iş sonuçlarına etkisi ve bir araştırma. Doktora Tezi. İstanbul Üniversitesi Sosyal Bilimler Enstitüsü.

Peker, S., İnandı, Y. ve Gılıç, F. (2018). The relationship between leadership styles (autocratic and democratic) of school administrators and the mobbing teachers suffer. European Journal of Contemporary Education, 7(1), 150-164.

Polat, S. (2007). Ortaöğretim öğretmenlerinin örgütsel adalet algıları, örgütsel güven düzeyleri ile örgütsel vatandaşlık davranışları arasındaki ilişki(Yayımlanmamış doktora tezi). Kocaeli Üniversitesi, Kocaeli.

Runciman, W. G. (1966). Relative deprivation and social justice: A study of attitudes to social inequality in twentieth-century England. Berkeley: University of California Press.

Runciman, W.G. (1996). Relative Deprivation and Social Justice. Berkeley and Los Angeles: University of California Press.

Schmitt M, Maes J, Widaman K (2010) Longitudinal effects of egoistic and fraternal relative deprivation on well-being and protest. Int J Psychol, 45:122-130

Suh, H. N.,ve Flores, L. Y. (2017). Relative deprivation and career decision self-efficacy: Influences of self-regulation and parental educational attainment. The Career Development Quarterly, 65(2), 145-158.

Tabachnick, B. G. ve Fidell, L. S. (2015). Using multivariate analysis. California State University Northridge: Harper Collins College Publishers.

Tavşancıl, E., Keser, H. (2002). İnternet kullanımına yönelik likert tipi bir tutum ölçeğinin geliştirilmesi. Eğitim Bilimleri ve Uygulama, 1(1), 79-100.

Toizer, B. (2016). Algılanan özcülük, grup göreceli yoksunluk ve toplu eylem (Doktora tezi, Oberlin Koleji). 
Toplu, D. (2010). Örgütsel adaletin yöneticiye güven üzerindeki etkisi ve bir araştırma. Yüksek Lisans Tezi, İstanbul Üniversitesi, İstanbul.

Turley, R. N. L. (2002). Is relative deprivation beneficial? The effects of richer and poorer neighbors on children's outcomes. Journal of community psychology, 30(6), 671-686.

Walker I (1999) Effects of personal and group relative deprivation on personal and collective self-esteem. Group Process Intergroup Relat, 2:365-380.

Walker, I. ve Mann, L. (1987). Unemployment, relative deprivation, and social protest. Personality and Social Psychology Bulletin, 13, 275-283. doi: 10.1177/0146167287132012

Walker, I. ve Pettigrew, T. F. (1984). Relative Deprivation Theory: An overview and conceptual critique. British Journal of Social Psychology, 23, 301-310.

Yilmaz, N. (2019). Hastanelerde çalışan kurum ev idaresi personelinin göreli yoksunluk duygusunun performansa etkisinin incelenmesi. Doktora Tezi. Hacettepe Üniversitesi Sosyal Bilimler Enstitüsü, Ankara

Yürür, Ş. (2008). Örgütsel adalet ile iş tatmini ve çalışanların bireysel özellikleri arasındaki ilişkilerin analizine yönelik bir araştırma. Süleyman Demirel Üniversitesi İ.I.B.F. Dergisi, 13(2), 295-312. 


\section{GÖRECELİ YOKSUNLUK ÖLÇEĞİ}

*Ters puanlanan madde.

\begin{tabular}{|c|c|c|c|c|c|c|}
\hline & & 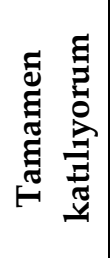 & $\underset{\Xi}{E}$ & 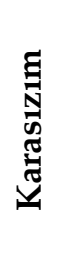 & 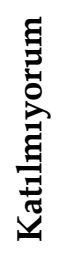 & 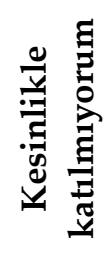 \\
\hline 1 & $\begin{array}{l}\text { Okul müdürü takdir edici tavırlarıyla okulda önemli } \\
\text { biri olduğumu hissettirir.* }\end{array}$ & 5 & 4 & 3 & 2 & 1 \\
\hline 2 & $\begin{array}{l}\text { Okul müdürünün çalışmalarımla ilgili olumsuz } \\
\text { eleştirisi beni mutsuz eder. }\end{array}$ & 5 & 4 & 3 & 2 & 1 \\
\hline 3 & $\begin{array}{l}\text { Haftalık ders programları hazırlarken okul müdürü } \\
\text { bazı öğretmenlere ayrıcalık tanır. }\end{array}$ & 5 & 4 & 3 & 2 & 1 \\
\hline 4 & $\begin{array}{l}\text { Okul müdürüyle çatışma yaşadığımda açı̆̆ımın } \\
\text { aranacağı hissine kapılırım. }\end{array}$ & 5 & 4 & 3 & 2 & 1 \\
\hline 5 & $\begin{array}{l}\text { Çalışma saatlerimde ihtiyaç duyduğumda okul } \\
\text { müdürü bana esneklik göstermez. }\end{array}$ & 5 & 4 & 3 & 2 & 1 \\
\hline 6 & $\begin{array}{l}\text { Müdürümüz başarılı sınıfları kendine yakın } \\
\text { öğretmenlere vermektedir. }\end{array}$ & 5 & 4 & 3 & 2 & 1 \\
\hline 7 & $\begin{array}{l}\text { Okulumuzda idari pozisyonlarda yönetime yakın } \\
\text { gruplardan kişiler vardır. }\end{array}$ & 5 & 4 & 3 & 2 & 1 \\
\hline 8 & $\begin{array}{l}\text { Okul müdürümün nöbet günlerimi ders programıma } \\
\text { uygun yapmaması beni kızdırır. }\end{array}$ & 5 & 4 & 3 & 2 & 1 \\
\hline 9 & $\begin{array}{l}\text { Okulumuzda ortak alınan kararlarda müdüre yakın } \\
\text { fikirler kabul görür. }\end{array}$ & 5 & 4 & 3 & 2 & 1 \\
\hline 10 & $\begin{array}{l}\text { Okulumdaki öğrenci başarılarında müdüre yakın } \\
\text { öğretmenlerin ön plana çıkarılması beni kızdırır. }\end{array}$ & 5 & 4 & 3 & 2 & 1 \\
\hline 11 & Sınıfım için alınan kararlarda benim fikrim alınır. ${ }^{*}$ & 5 & 4 & 3 & 2 & 1 \\
\hline 12 & Kendimi sürekli yenileme ihtiyacı duyarım. & 5 & 4 & 3 & 2 & 1 \\
\hline 13 & $\begin{array}{l}\text { Başarılı sonuçlar almak yeni öğretim yöntemleri } \\
\text { geliştirmemi sağlar. }\end{array}$ & 5 & 4 & 3 & 2 & 1 \\
\hline 14 & $\begin{array}{l}\text { Çalışmalarımın okul müdürü tarafında sürekli diğer } \\
\text { öğretmenlerle kıyaslanması beni mutsuz eder. }\end{array}$ & 5 & 4 & 3 & 2 & 1 \\
\hline 15 & $\begin{array}{l}\text { Aynı okulda çalıştığım arkadaşlarımla rekabet etmek } \\
\text { bende gerginlik yaratır. }\end{array}$ & 5 & 4 & 3 & 2 & 1 \\
\hline 16 & $\begin{array}{l}\text { Problemli sınıflar diğer öğretmenlere kıyasla daha } \\
\text { çok bana verilmektedir. }\end{array}$ & 5 & 4 & 3 & 2 & 1 \\
\hline 17 & $\begin{array}{l}\text { Okul müdürünün bana karşı haksız davranışları } \\
\text { bende okuldan ayrılma isteği uyandırır. }\end{array}$ & 5 & 4 & 3 & 2 & 1 \\
\hline 18 & $\begin{array}{l}\text { Müdürüm okul için yaptığım çalışmaları görmezden } \\
\text { gelir. }\end{array}$ & 5 & 4 & 3 & 2 & 1 \\
\hline 19 & $\begin{array}{l}\text { Müdüre yakın öğretmenler hak etmedikleri halde } \\
\text { itibar görür. }\end{array}$ & 5 & 4 & 3 & 2 & 1 \\
\hline 20 & $\begin{array}{l}\text { Öğretmenlik becerisine güvendiğim kimselerle } \\
\text { işbirliği yaparım. }\end{array}$ & 5 & 4 & 3 & 2 & 1 \\
\hline
\end{tabular}

